\title{
Review on the Effects of Seed Priming on Performance of Maize Seedlings
}

\author{
Abebe Misganaw* Mekdes Aklil Nega Kesete \\ College of Agricultural, Mekdela Amba University, Tuluawulia ,32, Ethiopia
}

\begin{abstract}
Maize (Zea mays L.) is members of the grass family, Poaceae (Gramineae). It is believed that the crop was originated in Mexico. Maize is an important food crop in southeastern Ethiopian produced in a number of agro ecologies in region. The main objective of this senior seminar is to review the effect of seed priming on performance of maize seedling. The effect of Priming and ambient temperature due to different sowing dates on emergence of maize seedlings. Seed priming also called is osmo conditioning is one of the most promising treatments for reducing the time needed between sowing and seedling emergence. Seeds planted in early spring frequently experience low temperatures stress in soil during Germination and early plant growth. All part of the crop can be used for food and non-food products. In industrialized countries, maize is largely used as livestock feed and as a raw material for industrial products. .Different factors, such as soil moisture stress, temperature extremities, and soil salinity, poor seed bed preparation, weed competition, low seed quality, and extreme disease pressure adversely affect the emergence of maize seed. Seed priming could be used as a viable technology to improve seedling establishment. Rapid and uniform emergence has been achieved by seed priming in some field. Seed priming is an effective technology to enhance rapid and uniform emergence and to achieve high vigour, leading to better stand establishment and yield.There are several priming techniques, such as hydro priming osmo priming, halo priming, matrix priming and bio priming.
\end{abstract}

Keywords: Seed physiological quality, Seed priming, Sowing date, Seedling emergence

DOI: $10.7176 / \mathrm{JBAH} / 10-14-05$

Publication date:July $31^{\text {st }} 2020$

\section{INTRODUCTION}

Maize $(2 n=2 x=20)$ is monoecious allogamous and highly cross pollinated crop and grass family Poaceae (Gramineae) (Ali et al., 2014 ).It is genetically accepted its center of origin is Mexico and Central America with domesticated starting 6,000 to 7,500 years ago in the Mexican highlands ( Doebley .2004).Francisco Hernandez Boncalo was the first to report the existence of this crop in 1570 and carried out the study of Mexico's flora with several evidences about maize by( Serratos-Hernandez .2009). Now maize is the second most grown cereal crop for human consumption after wheat globally critically in Sub Sharan Africa (SSA) including Ethiopia (Muli et al., 2016).Maize is extensively consumed in Central and West Africa used as raw materials in the food industry starting from 16th to 17th it has been highly and widely produced in Ethiopia in the mid and lowland sub humid areas of the country (Gemechu et al., 2016).

Ten to twelve thousand years ago, in independent locations around the world, cereal grains began to be consumed in larger quantities (Larson et al.,2014).Global maize agriculture was significantly enabled through adaptation to temperate environments that initially occurred during a 2000 -year period following introduction into the North American continent a 4000 years before present ( Swarts et al.,2017).Maize occupies approximately equal areas of production in the tropics and temperate environments, yet the majority $(70 \%)$ of maize production occurs under temperate conditions (Edmeades et al., 2017). Maize is the most popular and palatable feed for all kinds of livestock and poultry birds all over the world (Hossain and Shahjahan, 2007). It is one of the oldest humandomesticated plants (Abdolreza Abbassian, 2006). Maize is high yielding, easy to process, readily digested and cheaper than other cereals. It is also a versatile crop, growing across a wide range of agro ecological zones (Akinbode, 2010).

Maize is the most important staple in terms of calorie intake in rural Ethiopia. The 2004/5 national survey of consumption expenditure indicated that maize accounted for $16.7 \%$ of the national calorie intake followed by sorghum (14.1 \%) and wheat (12.6\%) among the major cereals (Berhane et al., 2011). Compared to the 1960s the share of maize consumption among cereals more than doubled to nearly $30 \%$ in the $2000 \mathrm{~s}$, whereas the share of teff, a cereal that occupies the largest area of all crops in Ethiopia, declined from more than $30 \%$ to about $18 \%$ during the same period (Demeke, 2012). Ethiopian farmers grow maize, primarily for subsistence with $75 \%$ of all maize output consumed by farming households, making. It a key crop for overall food security and for economic development in the country (CSA, 2018).

Conventional maize is used directly for human consumption as well as infant nutrition in the form of porridge during weaning period without any protein supplement such as egg, meat or beans, which are comparatively expensive especially for poor-resource in the rural area (Yusuf, 2010). Normal maize has 10\% protein which is of poor nutritional quality due to limiting concentration of essential amino acids (lysine and tryptophan) which the 
human body cannot synthesize and has to be supplemented ( Krivanek et al,. 2007). Therefore adoption and cultivation of QPM with high concentration of lysine and tryptophan contents therefore could drastically reduce malnutrition, diseases and death among low income maize consumers in the developing countries (Mbuya et al., 2011).

Seed priming, a promising technique have been successfully employed to overcome the problem associated with poor germination and subsequent terratic crop stand under normal and stressful conditions (Jafar et al.,2012; ). (Basra et al., 2011; Afzal et al., 2012) have e been tested to improve the maize performance under lown temperature stress. Kernel weight and composition can influence tolerance to cold stress, particularly in sweet corn, with heavier, kernels, containing higher starch, showing better germination( Trimble et al, 2016 ).In the field, small kernels may have lower emergence under cold conditions (Frascaroli et al.,2013). . Seed priming can increase emergence rate, early seedling growth and stand establishment in many plant species (Khan. et al., 2010)

Pre-sowing seed invigoration treatments have beneficial effect on field emergence, crop stand and seedling growth of Maize under low and sub-optimal temperatures (Rashid et al., 2002). Emergence performance of maize seeds varies with sowing dates due to variation in ambient temperature(Farooq et al., 2008). According to Basu et al. (2005) found that primed seed sown at higher temperature showed higher emergence performance and dry matter compared to low temperature. Medany et al., (2007) stated that optimum temperature for maize growing is between 25 and $30^{\circ} \mathrm{C}$. The objective of this paper is to review the effect of maize seed priming on seedling performance of maize

\section{LITERATUR EREVIEW}

\subsection{Origin and Botanical Description of the Maize}

Origins and taxonomic organization of maize was hotly debated until the late 1970s after which genetic studies, including the use of molecular markers and comparative DNA sequence data allowed breakthroughs in the taxonomy and phylogeny of maize and its wild relatives, including the identification of specific loci involved in the domestication process (van Heerwaarden et al., 2011). Maize was domesticated in the tropical lowlands of southwest Mexico with subsequent introgression from teosinte (Piperno et al., 2009; Huford et al., 2013).

Maize diversified under genetic drift and selection as it was carried through a diverse habitats during its spread by humans both south and north from its origin, including its arrival in the southwestern region of North America by 2260 BC (Merrill et al., 2009). The initial selection for adaptation to a temperate environment then occurred during the subsequent 2000 yrs. in North America (Bouchet et al., 2013). Maize has become adapted to the broadest range of climatic conditions of all crops, from 40S in Chile to $50 \mathrm{~N}$ in Canada and Russia, from sea level in the West Indies to elevations above $3400 \mathrm{~m}$ in the Andes (Bouchet et al., 2013). Maize is propagated by seed. Maize seed needs a soil that is warm moist well aerated and fine to give enough contact between the seed and the soil (Kassie et al., 2012).

\subsection{Agro-Ecologies and Production of Maize in Ethiopia}

The maize productivity gap between stressed and high potential areas is not only an issue of technology but also differences in climatic factors. Non- availability of suitable maize varieties is also responsible for such significant yield reduction (Mosisa et al., 2001).Unavailability of improved infrastructure and grain marketing represents major limiting factors for maize production. Wise utilization and conservation of natural resources will also have a significant impact on maize grain production (Mosisa et al., 2001). 
Table 1. Major agro-ecological zones for maize in Ethiopia (MOA 2005)

\begin{tabular}{|c|c|c|c|c|}
\hline $\begin{array}{l}\text { Agro- } \\
\text { Ecological zone }\end{array}$ & Elevation $(\mathrm{m})$ & $\begin{array}{l}\text { Rainfall } \\
(\mathrm{mm})\end{array}$ & $\begin{array}{l}\text { Estimate } \\
\text { Area } \\
(\%)\end{array}$ & Administrative regions \\
\hline $\begin{array}{l}\text { Moist and } \\
\text { semi-moist } \\
\text { mid-altitudes }\end{array}$ & $1700-2000$ & $\begin{array}{l}1000- \\
1200\end{array}$ & 30 & $\begin{array}{l}\text { Parts of South Netin National Part of region } \\
\text { ( SNNPR), south west (SW) and west ( W) } \\
\text { Oromia ;W and north west(NW) Amhara;Ben } \\
\text { Shangul- Gumuz (BSG) }\end{array}$ \\
\hline $\begin{array}{l}\text { Moist upper } \\
\text { mid-altitudes }\end{array}$ & $2000-2400$ & $>1200$ & 25 & $\begin{array}{l}\text { Central highlands; } \\
\text { High lands of SNNPR, }\end{array}$ \\
\hline $\begin{array}{l}\text { Dry mid- } \\
\text { altitudes }\end{array}$ & $1000-1600$ & $650-900$ & 20 & $\begin{array}{l}\text { Parts of SNNPR, south west ( SW) and } \\
\text { W Oromia; W and NW } \\
\text { Amhara; }\end{array}$ \\
\hline $\begin{array}{l}\text { Moist lower } \\
\text { mid-altitudes }\end{array}$ & $900-1500$ & $\begin{array}{l}900- \\
1200\end{array}$ & 15 & $\begin{array}{l}\text { Pockets of Amhara, } \\
\text { Oromia, SNNPR and BSG }\end{array}$ \\
\hline $\begin{array}{l}\text { Moist } \\
\text { lowlands }\end{array}$ & $<900$ & $\begin{array}{l}900- \\
1200\end{array}$ & 5 & Gambella and parts of BSG \\
\hline Dry lowlands & $<1000$ & $<700$ & 5 & Afar and parts of Oromia and lowlands of Somali \\
\hline
\end{tabular}

\subsection{Structure, Physiology and Breeding of Maize}

The maize plant is often $2.5 \mathrm{~m}$ (meters) $(8 \mathrm{ft})$ in height, though some natural strains can grow $12 \mathrm{~m}(40 \mathrm{ft})$. The stem has the appearance of a bamboo cane and is commonly composed of 20 internodes of $18 \mathrm{~cm}(7 \mathrm{in})$ length. (Aorta, 2012) A leaf grows from each node, which is generally $9 \mathrm{~cm}(3.5 \mathrm{in})$ in width and $120 \mathrm{~cm}$ (4ft) in length (Arora .2012) Ears develop above a few of the leaves in the midsection of $18 \mathrm{~cm}$. They are female inflorescences, tightly enveloped by several layers of ear leaves commonly called husks. Certain varieties of maize have been bred to produce many additional developed ears. These are the source of the baby corn used as a vegetable in Asian cuisine (Arora T. 2012). Most global production is provided by hybrid maize (Manuka et al., 2017a, b). Hybrids developed by CIMMYT yield $>20 \%$ more than OPVs under optimal conditions, and the disparity is magnified to $30->60 \%$ under a biotic and biotic stress conditions (Masuka et al., 2017a). However, open-pollinated varieties (OPVs) provide the majority of seed supply in some regions provided by the formal breeding sector (e.g., West Africa), albeit with much regional variation (Kassie et al., 2012) and due to many cited issues including seed supply (Gafney et al., 2016). More resources in terms of breeding support over a longer period of time have been directed toward maize improvement in temperate climates than have been applied, to date, to the improvement in maize production in the tropics (Edmeades et al., 2017) and heterotic patterns are not firmly established in tropical maize populations ( Wen et al., 2011).

\subsection{Seed Ageing and Salinity Induces Membrane Damage through Oxidative Stress}

Biochemical and physiological deterioration during seed aging has been studied mostly under accelerated aging conditions using high temperatures and high seed water content.(Oliveira et al., 2011a; )Some studies indicate that membrane lipid per oxidation is one of the major causes of seed aging under accelerated aging conditions (Oliveira et al., 2011a). However, plants contain numerous antioxidant compounds, both enzymatic and non-enzymatic, which act to prevent oxidative damage by scavenging free radicals before they attack membranes or other seed components (Bhaskaran and Panneerselvam, 2013). Some protective mechanisms involving free radical and peroxide scavenging enzymes, such as (CAT), (POX), (APX) and (SOD), have been evaluated within the mechanism of seed aging (Espanany et al., 2016).

Soil salinity may affect the germination of seeds and seedling establishment either by creating an osmotic potential external to the seed and roots, preventing water uptake, or through the toxic effects of sodium ion and Chlorine-ions on the germinating of the seed and plant growth (Iqbal and Ashraf, 2013). In addition to ionic and osmotic components, salt stress, e.g. accelerated aging of seeds, also leads to oxidative stress through an increase in reactive oxygen species (ROS), such as, hydrogen peroxide $\left(\mathrm{H}_{2} \mathrm{O}_{2}\right)$ and hydroxyl radicals $(\mathrm{OH})(\mathrm{Bhaskaran}$ and Panneerselvam, 2013).

\subsection{Priming Effect on the Physiological Potential of Maize Seeds under Abiotic Stress}

Seed priming may be an alternative for improving seed vigor. Priming may be performed with the use of substances 
that contribute to the expression of the seed physiological potential (Batista, 2016). Seed priming may promote more balanced germination rates and higher germination speed, in addition to faster seedling growth under adverse conditions, for instance, under a biotic stress (Arif et al., 2014). However, few studies have been conducted on seed priming using the amino acid phenylalanine, which is a precursor of phenolic compounds that increase in response to different types of stress, e.g., related to the plant defense systems and adaptation to adverse situations (Stangarlin, 2011). According to Batista (2016), priming with chemical enhances physiological seed quality, producing seeds with high tolerance to stress under high temperature.

\subsection{Effect of Seed Priming on Seed Vigor and Early Growth in Maize}

2.6.1. Under suboptimal temperature condition

Low temperature is one of the major environmental factor that has a significant influence on the growth and development of plants (Farooq et al., 2008a). The negative impact of low temperatures on plant metabolism can be detected from the cellular level to the level of the whole plant (Gay et al., 2008). The potential visual symptoms of chilling injuries in chilling-sensitive plants are leaf and hypocotyls wilting, the appearance of surface pits and large cavities, leaf necrosis, accelerated aging and the rupture of injured tissues, delayed, partial, or uneven ripening and growth decreasing, low temperature stress disturbs cells ultra-structure, enzyme activity, mitochondrial respiratory activity and electron transport (Gay et al., 2008).Accord mining to Saeidnejad et al., (2012) review that low temperature decreased maize seed germination parameters, seedling emergence and growth. Low temperature had deleterious effect on membrane stability, relative water content, starch metabolism and antioxidant activities (Farooq et al., 2008a).

2.6.2. Under optimum temperature conditions

The optimum temperature for the germination of maize seed ranges from 25 to $28{ }^{\circ} \mathrm{C}$. A stressful condition in germination lowers the plant population, which leads to reduction of grain yield (Radić et al., 2009).

\subsection{Different Effects of Seed Priming Techniques can Improve Seed Vigor and Early Seedlings Growth.}

There are several priming techniques, such as hydro priming (Kaya et al., 2006), osmo priming (Foti et al., 2008), halo priming (Patade et al., 2012), matrix priming (Zhang et al., 2007) and bio priming (Begum et al., 2010).The two most commonly used seed priming methods are hydro priming and osmo priming.

\section{$>$ Hydro priming}

Hydro priming is the simplest method of seed priming, which relies on seed soaking in pure water and re-drying to original moisture content prior to sowing. (Goswami et al., 2013).It is easily available and uncostly pre-sowing treatment, where seed hydration is achieved by soaking seeds in water (Casenave and Toselli, 2007). Kaya et al. (2006) According to this review hydro priming increased germination and seedling growth under salt and drought stress during germination in sunflower. Hydro-priming plays an important role in the seed germination, radical and plumule emergence in different crop species under saline and non-saline conditions and also have beneficial effect on enzyme activity required for rapid germination. (Rahman et al., 2011).

Beneficial effect of hydro priming on seed germination and seedling growth under both optimal and stress conditions, in various crop plants such as chickpea, maize, rice mung bean and capsicum has been observed (Posmyk and Janas, 2007 and Patade et al., 2012). Harris (2006) has reported improvement in seed yield in various crops at farmer's field by seed priming with water. Caseiro et al., (2004) found that hydro-priming was the most effective method for improving seed germination of onion, especially when the seeds were hydrated for $96 \mathrm{hr}$ compared to $48 \mathrm{hr}$. The main disadvantages of hydro priming is uncontrolled water uptake by seeds (Caseiro et al. ,2004).This is a consequence of free water availability to seeds during hydro priming, so that the rate of water uptake depends only on seed tissue affinity to water (Caseiro et al. ,2004).

\section{$>$ Bio priming}

Bio priming involves seed imbibition together with bacterial inoculation of seed (Gulick et al., 2012). As other priming method, this treatment increases rate and uniformity of germination, but additionally protects seeds against the soil and seed-borne pathogens. (Gulick et al., 2012). It was found that bio priming is a much more effective approach to disease management than other techniques such as pelleting and film coating (Muller and Berg, 2008). Nowadays, the use of bio priming with plant growth-promoting bacteria as an integral component of agricultural practice (Timmusk et al., 2014). In pearl millet, bio priming with Pseudomonas fluorescent isolates enhanced plant growth and resistance against downy mildew disease (Raj et al., 2004). Bio priming with rhizo bacteria improved germination parameters of radish seeds under saline conditions (Kaymak et al., 2009).

\section{$>$ Osmo priming}

It is standard priming method that involves the use of adverse osmotic solution like mannitol, polyethylene glycol or salts such as chlorides, sulphates, nitrates to control water potential (Chen et al., 2010; Papastylianou and Karamanos, 2012). The usefulness of osmo priming with Potassium Nitrite (KNO3) was shown in different plant species (Kaya et al., 2006; Eskandari and Kazemi, 2011).Osmo priming is the most widely used type of seed priming in which seeds are soaked in aerated low water potential solution. Priming of seeds in osmoticums has 
been reported to be an economical, simple and a safe technique for seedling establishment and crop production under stressed conditions (Guzman and Olave, 2006).

\section{$>\quad$ Solid matric priming}

Solid matrix priming (SMP), matric conditioning in which water uptake by seeds is controlled (McDonald, 2000). The use of solid medium allows seeds to hydrate slowly and simulates natural imbibition process occurring in the soil (McDonald, 2000).

\section{$>$ Halo priming}

Halo-priming refers to soaking of seeds in solution of inorganic salts i.e., sodium chloride $(\mathrm{NaCl})$, Potassium Nitrite $\left(\mathrm{KNO}_{3}\right)$ and Calcium dichloride $\left(\mathrm{CaCl}_{2}\right)$ e.t.c. A number of studies have shown a significant improvement in seed germination, seedling emergence and establishment and final crop yield in salt affected soil in response to halo-priming (Iqbal et al; 2006). Priming with sodium chloride $(\mathrm{NaCl})$ and Potassium chloride (KCl) was helpful in removing the deleterious effects of salts (Iqbal et al., 2006). It is a pre-sowing soaking of seeds in salt solutions, which enhances germination and seedling emergence uniformly under adverse environmental conditions and normal condition. Inorganic salts are used. Review the effects of sodium chloride $(\mathrm{NaCl})$ priming with potassium Nitrite ( KNO3) on the germination traits and seedling growth of four Helianthus annuus Cultivars under salinity conditions and review that germination percentage of primed seeds was greater than that of un-primed seeds( Bajehbaj, 2010).

\section{$>$ Hormonal priming}

It is soaking of seed in hormone solution is referred as hormonal priming. GA3, Salicylic acid, Ascorbic acid, Cytokine's etc. can be used for this investigated the primed seeds of carrot, onion and tomato showing that priming these seeds with GA3 increased the germination percentage and rate (fzal et al., 2006). Review that the effect of hormonal priming with ABA, salicylic acid, or ascorbic acid on Wheat germination and seedling growth under normal and saline conditions (Bahrani and Pourreza, 2012).

\subsection{Effect of Seed Priming on Maize Seedling Emergence}

Different factors, such as soil moisture stress, temperature extremities, and soil salinity, poor seed bed preparation, weed competition, low seed quality, and extreme disease pressure adversely affect the emergence of maize seed. Seed priming could be used as a viable technology to improve seedling establishment. Rapid and uniform emergence has been achieved by seed priming in some field crops (Murungu et al., 2004).

\subsection{Importance of Seed Priming in Plant G}

\section{* Germination}

Primed seeds enhanced uniform seedling emergence which may contribute to regular crop establishment, it often exhibit an increased germination rate and greater germination uniformity (Galhaut et al., 2014).Priming may also induce structural and ultra-structural modifications that could facilitate subsequent water uptake and attenuate initial differences between the seeds in terms of imbibition, thus resulting in a more uniform germination (Galhaut et al., 2014). In mung bean plants, faster seedling establishment resulting from priming may contribute to a total increase in yield up to 45\% (Rashid et al., 2004). Priming- induced increase in germination may be associated to a change in plant hormone biosynthesis and signaling. Priming has been reported to increase gibberellins (GA)/abscisic acid (ABA) ratio (El-Arab et al., 2006) and this may be a direct consequence of a priming impact in gene expression pattern (Schwember et al., 2010). Ethylene also directly influences germination speed and percentage. Increase in ethylene production during priming may promote endo- $\beta$-mannase activity facilitating endosperm weakening and post-priming germination (Chen and Arora, 2013).

\section{* Plant growth and development}

Plants produced from primed seeds often exhibit a faster growth than unprimed ones (Chen and Arora, 2013). The beneficial impact of priming on plant growth may be due to an improved nutrient use efficiency allowing a higher relative growth rate (Muhammad et al., 2015). A higher growth of seedlings issued from primed seeds may also be analyzed in relation to a direct impact of pretreatment on cell cycle regulation and cell elongation processes (Chen and Arora, 2013). The growth parameters of chickpea were significantly affected by seed priming (Guptaand Singh, 2012).

\section{- Yield}

Yield increase may also result from a higher plant density observed as a -consequence of priming-induced increase in germination percentage (Murungu et al., 2004 and Harris et al., 2004). Seed priming treatment resulted in increased crop growth rate in treated sets which encouraged deposition of more photo assimilates in key plant parts, greatly affecting the final yield (Srivastava and Bose, 2012). Highest grain yield of Pusa Basmati 1121 was obtained with hydro-priming at $60 \mathrm{~kg} / \mathrm{ha}$ of $\mathrm{N}$ application applied in 3 splits (Mahajan et al., 2011). Binang et al. (2012) also demonstrated that priming had a significant effect on the number of tillers number of fertile panicles, and consequently grain yield of new rice varieties. 


\section{CONCLUSION}

This review summered that suboptimal temperatures had negative effects on seed vigor and early seedlings growth. Seed priming treatments had more improving effects on review seed and seedlings traits under suboptimal (low and mixed temperature) than at optimal conditions. The beneficial effects of priming have also been proven in germination and the emergence of seeds and seedlings in many crops, particularly under a biotic stress. The improvements in the physiological quality of seeds and seedling vigor by seed priming under a biotic stress conditions has been related to the repair and build-up of nucleic acids, the increased synthesis of proteins, osmotic adjustment mechanisms. Seed priming is an effective technology to enhance rapid and uniform emergence and to achieve high vigour, leading to better stand establishment and yield .There are several priming techniques, such as hydro priming osmo priming, halo priming, matrix priming and bio priming. The two most commonly used seed priming methods are hydro priming and osmo priming. Seed priming is an old empirical strategy used since centuries by farmers, and since decades by seed companies, to improve germination processes in cultivated plant species. The underlying mechanisms involved in this positive impact of pre- sowing treatments remained obscure for a long time. The present review aimed to summarize recent information provided by various tools allowing the identification of molecular cues conditioning priming efficiency.

\section{REFERENCES}

Abdolreza Abbassian. 2006. Maize International Market Profile Competitive Commercial Agriculture in Sub Saharan Africa (CCAA) Studs Trade and Markets Division Food and Agriculture Organization of the United Nation. Acland J. D.1977. East African Crops, FAO, Longma. P. 252

Afzal I, Basara SMA, Farooq M, Nawazi A. 2006. Alleviation of salinity stress in spring wheat by hormonal priming with ABA, Salicylic Acid and Ascorbic Acid. International journal of Agriculture and Biology. $8(1): 1560-8530$

Afzal I, Hussain B, Basra S M A, Rehman H. 2012. Priming with MLE reduces imbibitional chilling injury in spring maize. Seed Science and Technology, 40, 271- 276.

Akinbode OA 2010. Evaluation of antifungal efficacy of some plant extracts on Curvularia lunata, the causal organism of maize leaf spot, Afr. J. Env.Sci. Tech., 4(11): 797-800.

Ali Q, Ahsan M, Ali F, Ali A, Kanwal N. 2014. Genetic correlation and hybrid vigor for physiological traits of zea mays. Nat Sci, 2014, 12: 50-59

ARIF, M.2014. Evaluating the impact of osmopriming varying with polyethylene glycol concentrations and durations on soybean. International Journal of Agriculture and Biology, v. 16, n. 2, p. 359-364,

Arora, T.2012.The plant length is measured by using the different unit of measurement to know its development from time to tim

Bahrani A, Pourreza J. Gibberlic Acid and Salicylic Acid effects on seed germination and seedlings growth of Wheat (Triticum aestivum L.) under salt stress condition. World Applied Sciences Journal. 2012; 18(5):633641.

Bajehbaj $\mathrm{AF}$. The effects of $\mathrm{NaCl}$ priming on salt tolerance in sunflower germination and seedling grown under salinity conditions. African Journal of Biotechnology. 2010; 12:1764-1770.

Basra S M A, Iftikhar M N, Afzal I. 2011. Potential of moringa (Moringa oleifera) leaf extract as priming agent for hybrid maize seeds. International Journal of Agriculture and Biology, 13, 1006-1010.

Basu, S., S.P. Sharma and M. Dadlani. 2005. Effect of hydropriming on field emergence, crop performance and seed yield of maize parental lines during winter and spring-summer season. Seed Res. 33(1): 24-27.

Batista, T. B 2016: Priming and stress under high humidity and temperature on the physiological quality of Brachiaria brizantha cv. MG-5 seeds. Acta Scientiarum, v.38, n. 1, p. 123-127, 20

Begum MM, Sariah M, Puteh AB, Zainal Abidin MA, Rahman MA, Siddiquai 2010: Field performance of bioprimed seeds to suppress Colleto trichum truncatum causing damping-off and seedling stand of soybean. Biological Control. 53(1): 18-23.

Berhane, G.,Paulos,Z., Tafere, K., \& Tamru, S. 2011. Food grain consumption and calorie intake patterns in Ethiopia. AddisAbaba: IFPRI.

Bhaskaran J, Panneerselvam R 2013 Accelerated reactive oxygen scavenging system and membrane integrity of two panicum species varying in salt tolerance. Cell Biochem Biophys 67:885-892.

Binang, W.B., Shiyam, J.Q. and Ntia, J.D. 2012. Effect of seed priming method on agronomic performances and cost effectiveness of rain fed, dry-seeded NERICA rice. Research Journal of Seed Science.5:136-143.

Bouchet S, Servin B, Bertin P, Madur D, Combes V, Dumas F, Brunel D, Laborde J, Charcosset A, Nicolas S 2013 Adaptation of maize to temperate climates: mid-density genome-wide association genetics and diversity patterns reveal ke genomic regions, with a major contribution of the Vgt2 (ZCN8) locus. PLoS ONE 8(8):e71377

Burbano HA 2017 Genomic estimation of complex traits reveals ancient maize adaptation to temperate North America. Science 357:512-515 
Caseiro, R., Bennett, M.A. andMarcos, Filho. J. 2004. Comparison of three priming techniques for onion seed lots differing in initial seed quality. Seed Sci Tech. 32:365-375.

Casenave EC and Toselli ME 2007: Hydropriming as a pre-treatment for cotton germination under thermal and water stress conditions. Seed Sci. Technol. 35: 88 -98.

Chen K, Arora R, Arora U 2010: Osmopriming of spinach (Spinacia oleracea L. cv. Bloomsdale) seeds and germination performance under temperature and water stress. Seed Sci. Technol. 38: 36-48.

Chen, K. and Arora, R. 2013.Priming memory invokes seed stress-tolerance. Environmental and Experimental Botany. 94:33-45.

CSA (2013). Agricultural Sample Survey 2012/2013: Report on area and production of major crops (private, peasant holdings, 'Meher' season).Statistical Bulletin. Vol.1, Addis Ababa: CSA.

Demeke, M. 2012. Analysis of incentives and disincentives for maize in Ethiopia. Technical notes series, MAFAP. Rome: FAO.

Doebley J. The genetics of maize evolution. Annu Rev Genet, 2004, 38: 37-59. Serratos-Hernandez J. The origin and diversity of maize in the American continent. Ed Green Peace, 2009.

Edmeades GO, Trevisan W, Prasanna BM, Campos H 2017 Tropical maize (Zea mays L.). In: Campos H, Caligari PDS (eds) Genetic improvement of tropical crops. Springer, New York, pp 57-109

Edmeades GO, Trevisan W, Prasanna BM, Campos H 2017 Tropical maize (Zea mays L.). In: Campos H, Caligari PDS (eds) Genetic improvement of tropical crops. Springer, New York, pp 57-109

El-Araby, M.M., Moustafa, S.M.A., Ismail, A.I. and Hegazi, A.Z.A. 2006. Hormones and phenol levels during germination and osmopriming of tomato seeds, and associated variation in protein patterns and anatomical seed features.Acta Agronomica Hungarians. 54:441-458

Eskandari H and Kazemi K 2011: Effect of seed priming on germination properties and seedling establishment of cowpea (Vigna sinensis). Not. Sci. Biol. 3(4): 113-116.

Espanany A, Fallah S, Tadayyon A 2016 Seed priming improves seed germination and reduces oxidative stress in black cumin (Nigella sativa) in presence of cadmium. Ind Crops Prod. 79: 195-204.

Farooq M, Aziz T, Basra SMA, Wahid A, Khaliq A, Cheema MA 2008a: Exploring the role of calcium to improve chilling tolerance in hybrid maize. J. Agron. Crop Sci. 194: 350-359.

Farooq, M., T. Aziz, S.M.A. Basra, M.A. Cheemaand H. Rehman. 2008. Chilling tolerance in hybrid maize induced by seed priming with salicylic acid. J. Agron. and Crop Sci. 194(2):161-168.

Foti R, Abureni K, Tigere A, Gotosa J, Gere J 2000: The efficacy of different seed priming osmotica on the establishment of maize(Zea mays L.) caryopses. J. Arid. Environ. 72: 1127-1130.

Frascaroli E, Landi P. Divergen selection in a maize population fogermination at low temperature in controlled environment: study of the direct response, of the trait inheritance and of correlated responses in the field. Theoretical and Applied Genetics.2013;126(3):733-46. 10.1007 s00122-012-2014-4 [PubMed] [CrossRef][Google Scholar ]

Gafney J, Anderson J, Franks C,Collinson S, MacRobert J, Woldemariam W, Albertsen MC 2016 Robust seed systems, emerging technologies and hybrid crops for Africa. Food Secur. 9:36-44

Galhaut, L., Lespinay, A., Walker, D.J., Bernal, M.P., Correal, E. and Lutts, S. 2014. Seed priming ofTrifolium ripens L. improved germination and early seedling growth on heavy metal contaminated soil. Water Air Soil Pollution. 225:1-15.

Gay C, Kaplan F, Kopka J, Selbig J, Hincha DK 2008: Metabolomics of temperature stress. Physiol. Plant. 132: 220-235.

Gemechu N, Sentayehu A, Leta T. Review on quality protein maize breeding for Ethiopia. Journal of Biology, Agriculture and Health Care, 2016

Goswami, A., Banerjee, R. and Raha, S. 2013. Drought resistance in rice seedlings conferred by seed priming: role of the anti-oxidant defense mechanisms.Protoplasma. 250:1115-29.

Gulick, B.R. 2012. Plant Growth-Promoting Bacteria: Mechanisms and Applications. Hindawi Publishing Corporation, Scientifica. Pp.1-15.

Gupta, V. and Singh, M. 2012. Effect of seed priming and fungicide treatment on chickpea (Cicer arietinum) sown at different sowing depths in kandi belt of low altitude sub-tropical zone of Jammu. Applied Bio Res. 14: 187-92

Harris, D. 2006. 'On-farm' seed priming. A key technology to improve the livelihoods of resource-poor farmers in marginal environments (extended version). DFID/PSP information booklet, CAZS Natural Resources, University of Wales, Bangor, UK.

Hossain, A. and M. Shahjahan. 2007. Grain quality evaluation of the major varieties or cultivar of maize. Research report of the year 2006-07. Post harvest Technology

Huford MB, Lubinksy P, Pyhäjärvi T, Devengenzo MT, Ellstrand NC, Ross-Ibara J 2013 Correction: the genomic signature of crop-wild introgression in maize. PLOS Genetics. https://doiorg/10.1371/annotation/2eef7b5b29b2-412f-8472- 8fd7f9bd65 
Iqbal M,Ashraf M 2013 Gibberellic acid mediated induction of salt tolerance in wheat plants: Growth, ionic partitioning, photosynthesis, yield and hormonal homeostasis. Environ Exp Bot. 86:76-85.

Iqbal, M., Ashraf, M., Jamil, A.and Rehmaan, S. 2006. Does seed priming induce 2395 changes in the level of some endogenous plant hormones in hexaploi wheat plant under salt stress. J Int Pl Bio. 48181-89.

Jafar M Z, Farooq M, Cheema M A, Afzal I, Basra S M A, Wahid M A, Aziz T, Shahid M.2012. Improving the performance of wheat by seed priming under saline conditions. Journal of Agronomy and Crop Sciences, 198, $38-45$.

Kassie GT, Erenstein O, Mwangi W, La Rovere R, Setimela P, Langyintuo A 2012 Characterization of maize production in southern. Africa: synthesis of CIMMYT/DTMA household level farming system surveys in Angola, Malawi, Mozambique, Zambia and Zimbabwe. Socio-economics program working paper 4. CIMMYT, Mexico, D.F

Kaya MD, Okcu G, Atak M, Cikili Y, Kolsarici O 2006: Seed treatments to overcome salt and drought stress during germination in sunflower (Helianthus annuus L.). Europ. J. Agron. 24: 291-295.

Kaymak, H.C., Guvenc, I., Yarali, F. and Donmez, M.F. 2009. The effects of biopriming with PGPR on germination of radish (Raphanus sativus L.) seeds under saline conditions. Turkish Journal of Agriculture and Forestry. 33:173-179.

Khan AK. Pre plant physiological seed conditioning New York, NY: John Wiley and Sons, Inc.; 2010. p. 13182.[Google Scholar ]

Krivanek AF, Hugo DG, Nilupa SG, Alpha OD and Dennis F 2007. Breeding and disseminating quality protein maize(QPM) for Africa. Afr. J. Biotechnol. 6(4): 312-324.

Larson 2014,Rashid, A., D. Harris, P.A. Shillington and R.A. Khattak. 2002. On- farm seed priming: a key technology for improving the livelihood of resource poor farmers on saline lands. Centre for Arid Zone studies, University of Wales, UK, Pp.37-39.

Mosisa et al.,2001. Wise utilization and conservation of natural resources will have a significant impact on maize grain production

Masuka B, Atlin GN, Olsen M, Magorokosho C, Labuschagne M, Crossa J, Banziger M, Pixley KV, Vivek B,Biljon A, MacRobert JF, Alvarado G, PrasannaBM, Makumbi D, Makumbi D, Tarekegne AT, Das B, Zaman-Allah M, Cairns JE 2017a Gains in maize genetic improvement in Eastern and Southern Africa : I. CIMMYT hybrid breeding pipeline. Crop Sci 57:168-179

Masuka B, Magorokosho C, Olsen M, Atlin GN, Bänziger M, Pixley KV, Vivek BS, Labuschagne M, MatembaMutasa R, BurgueñoJ,Macrobert J, Prasanna BM, Das B, Makumbi D, Tarekegne A, Crossa J, Zaman-Allah M, van Biljon A, Cairns JE 2017b Gains in maize genetic improvement in Eastern and Southern Africa: II. CIMMYT open-pollinated variety breeding pipeline. Crop Sci 57:180-191

Mbuya K, Nkongolo KK and Kalonji-Mbuyi A 2011. Nutrition analysis of quality protein maize selected for agronomic characteristics in a breeding program. Int. J. Plant Breed. Genet., 2(11): 325-332

McDonald, M. B. 2000. Seed Priming. In: Seed Technology and its Biological Basis, Black, M. and Bewley, J. D. (Eds.). Shefield Academic Press, Shefield, UK, pp:287-325.

Medany, M.A., A.K. Hegazy, H.F. Kabiel and M.M. Maez. 2007. Prediction of seed germination and seedling growth of crop plants as affected by root zone temperature. World J. Agril. Sci.3 (6): 714-720.

Merrill WL, Hard RJ, Mabry JB, Fritz GJ, Adams KR, Roney JR, MacWilliams AC 2009 The diffusion of maize to the south western United States and its impact. Proc Natl Acad SciUSA 106:21019-21026

MOA. 2005. New agro-ecological zones of Ethiopia. Addis Ababa:Ministry of Agriculture.

Muhammad, I., Kolla, M., Volker, R. and Günter, N. 2015. Impact of nutrient seed priming on germination, seedling development, nutritional status and grain yield of maize. Journal of Plant Nutrition.38:1803-1821.

Muli JK, Budambula NL, Mweu C, Imbo MC, Anami SE, et al. Genetic improvement of african maize towards drought tolerance: A Review. 2016

Müller, H. and Berg, G. 2008. Impact of formulation procedures on the effect of the biocontrol agent Serratia plymuthica HRO-C48 on Verticillium wilt in oilseed rape. BioControl. 53: 305-316.

Murungu, F.S., C. Chiduza, P. Nyamugafata, L.J. Clark, W.R. Whalley and W.E. Finch Savage. 2004. Effects of on-farm seed priming on consecutive daily sowing occasions on the emergence and growth of maize in semiarid Zimbabwe. Field Crops Res. 89(1): 49-57.

Oliveira AB, Gomes-Filho E, Enéas-Filho J, Prisco JT, Alencar NLM 2011a Seed priming effects on growth, lipid per oxidation, and activity of ROS scavenging enzymes in NaCl-stressed sorghum seedlings from aged seeds. J Plant Interact. 7:151-159.

Papastylianou PT and Karamanos AJ 2012: Effect of osmopriming treatments with mannitol on cotton seed germination performance under suboptimal conditions. Seed Sci. Technol.40: 248-258.

Patade VY, Bhargava S, and Suprasanna P 2012: Halopriming mediated salt and isoosmotic PEG stress tolerance and, gene expression profiling in sugarcane (Saccharum officinarum L.). Mol. Biol. Rep. 39: 9563-9572.

Patade, V.Y., Khatri, D., Manoj, K., Kumari, M. and Ahmed, Z. 2012. Cold tolerance in thiourea primed capsicum 
seedlings is associated with transcript regulation of stress responsive genes. Molecular Biology Reports. 39:10603-10613

Piperno DR, Ranere AJ, Holst I,Inarte J, Dickau R 2009 Starchgrain and phytolith evidence for early ninth millennium B.P. maize from the Central Balsas River Valley. Mexico. Proc NatlAcad Sci USA 106:50195024

Posmyk, M.M. and Janas, K.M. 2007. Effects of seed hydropriming in presence of exogenous pralines on chilling injury limitation in Vigna radiata L. seedlings. Acta Physiologiae Plant arum. 29:509-517

Radić V, Mrđa J, Marjanović-Jeromela A, Prole S, Jokić G, Marinković R, Miklič V 2009: Corn seedling sensitivity on stressful conditions. Selekcijai semenarstvo. 15 (4): 21-27

Raj, N.S., Shetty, N.P. and Shetty, H.S. 2004. Seed bio-priming with Pseudomonas fluoresces isolates enhances growth of pearl millet plants and induces resistance against downy mildew. International Journal of Pest Management. 50:41-48.

Rashid, A., Harris, D., Hollington, P.and Ali, S. 2004. On-farm seed priming reduces yield losses of mungbean (Vignaradiata) associated with moonbeam yellow mosaic virus in the North West Frontier Province of Pakistan. Crop Protection. 23:1119-1124.

Rehman, H. U., Maqsood, S., Basra, A. and Farooq, M. 2011. Field appraisal of seed priming to improve the growth, yield and quality of direct seeded rice. Turk J Agric. 35: 357-65.

Saeidnejad AH, Pouramir F, Naghizadeh M 2012: Improving chilling tolerance of maize seedlings under cold conditions by spermine application. Not. Bot. Sci. 4: 110-117.

Schwember, A.R. and Bradford, K.J. 2010. A genetic locus and gene expression pattern associated with the priming effect on lettuce seed germination at elevated temperature. Plant Molecular Biology.73: 105-118.

Srivastava, A. K. and Bose, B. 2012. Effect of nitrate seed priming on phenology, growth rate and yield attributes in rice (Oryza sativa L.). Vegetos. 25: 174-81.

stangarlin, J. R.2011. Adefesa vegetal contra fitopatógenos. Scientia Agraria Paranaenis, v. 10, n. 1, p. 18-46, 2011.

Swarts K, Gutaker RM, Benz B, Blake M, Bukowski R, Holland J, Kruse-Peeples M, epak N, Prim L, Cinta Romay M, RossIbarra J, de Jesus Sanchez-Gonzalez J, Schmidt C, Schuenemann VJ,Krause J, Matson RG, Weigel D, Buckler ES,

Timmusk, S, Abd El-Daim, I.A., Copolovici, L., Tanilas, T., Kannaste, A., Behers, L., Nevo, E., Seisenbaeva, G., Stenstrom, E. and Niinemets, U. 2014. Drought tolerance of wheat improved by rhizosphere bacteria from harsh environments: enhanced biomass production and reduced emissions of stress volatiles. PLoS One. 9 (5):e96086.

Trimble L, Shuler S, Tracy W.Characterization of five naturally occurring alleles at the sugaryl locus for seed composition, seedling emergence, and isoamylaselactivity.CropScience.2016;56(4):1927-39. 10.2135/cropsci2015.02.0117 [CrossRef] [Google Scholar]

van Heerwaarden J, Doebley J, Briggs WH, Glaubitz JC, Goodman MM, de Jesus Sanchez Gonzalez J, RossIbarra J 2011 Genetic signals of origin, spread, and introgression in a large sample of maize landraces. Proc Natl Acad Sci USA 108:1088-1092

Wen W, Araus JL, Shah T, Cairns J, Mahuku G, Bänziger M, Torres JL, Sánchez C, Yan J 2011 Molecular characterization of a diverse maize inbred line collection and its potential utilization for stress tolerance improvement. Crop Sci 51:2569-2581

Yusuf M 2010. Genetic variability and correlation in single cross hybrids of quality protein maize (Zea mays L.). Afr. J. Food Agric. Nutrit. Dev., 10(2): 2166-2175.

Zhang CF, Hu J, Lou J, Zhang Y, Hu WHM 2007: Sand priming in relation to physiological changes in seed germination and seedling growth of waxy maize under high-salt stress Seed Sci. Technol. 35: 733-738 